\title{
The Semantics of still and the Modification of Polish Adnominal Participles
}

\begin{abstract}
Polish adnominal participles accept a wide range of event modifiers except when they are additionally modified by focus or phase particles corresponding to still. The paper argues that the semantic contribution of still is incompatible with the change-of-state component of the meaning of participles. While still presupposes that the property denoted by the participle holds over the initial proper subinterval during which the focalized state holds, the measure-of-change function found in resultative participles entails that the relevant subinterval corresponds to the change of state over which the relevant property does not hold yet. The participles modifiable by still are argued to lack the change-of-state component.
\end{abstract}

\section{Keywords}

participles, passives, degree achievements, focus particles, adverbials

\section{Introduction}

As visible in (1a-b) Polish adnominal adjectival participles also referred to as resultative adjectives (Cetnarowska 2000) can be modified by the equivalents of the focus particle still or by temporal completion and locative adverbials as well as agentive $b y$-phrases. What is not possible is the combination of the two classes of modifiers within a single phrase (1c).
(1) a. ciagle $\sim w c i a ̨ z \dot{z}$ jeszcze still $1 /$ still $_{2}$
prze-mocz-on-e
ubrani-e 'clothes that are still soaked'

\section{clothing-NOM.SG}

\footnotetext{
${ }^{1}$ The grammatical information has been omitted in the glosses except where it is crucial. The paper uses the following set of abbreviations: $\mathrm{F}=$ feminine, $\mathrm{M}=$ masculine, $\mathrm{N}=$ neuter, $\mathrm{NOM}=$ nominative, $\mathrm{NVIR}=$ non-virile, $\mathrm{PL}=$ plural, $\mathrm{PTCP}=$ participle, $\mathrm{SG}=$ singular, $\mathrm{TH}=$ thematic element .
} 
b. prze-mocz-on-e celowo przez Tomka through-wet-PTCP-NOM.SG.N purposefully by Tomek $w 5$ minut, $\quad w$ ogrodzie ubrani-e in 5 minutes in garden clothing-NOM.SG

'clothes that have been soaked on purpose, by Tomek in 5 minutes in the garden'

$\begin{array}{lll}\text { c. }{ }^{*} \text { ciagle } \sim \text { wciążjeszcze } & \begin{array}{l}\text { prze-mocz-on-e } \\ \text { through-wet-PTCP-NOM.SG.N }\end{array} & \begin{array}{l}\text { celowo, } \\ \text { still1/still2 }\end{array}\end{array}$

przez Tomka, w 5 minut, $w$ ogrodzie ubrani-e by Tomek in 5 minutes in garden clothing-NOM.SG Intended: 'clothes that have been soaked on purpose, by Tomek in 5 minutes in the garden and are still soaked'

Anagnostopoulou (2003, 2017), Alexiadou et al. (2015) and Bondaruk and Rozwadowska (2018) among others treat the incompatibility of participles modified by still with event modification as the property of the entire class of target state passives. Since the participles modified by still are unambiguously target state passives and still-modified constructions are incompatible with event modifiers, target state passives are incompatible with event modifiers.

In what follows I will show that this view is not necessarily correct in the case of Polish adnominal participles and I will argue that the unacceptability of examples such as (1c) is the consequence of the incompatibility of the Polish equivalents of still with telic degree achievement predicates and the incompatibility of event modifiers with predicates that lack the relevant aspectual specification.

In section $2 \mathrm{I}$ argue that a very common analysis according to which adnominal participles are reduced relative clauses is extremely difficult to maintain in Polish. Section 3.1. discusses the details of the patterns of modification attested with adnominal participles and focuses on their (in)compatibility with the focus particles ciagle wcią $z$ 'still1' and jeszcze 'still2', while section 3.2 focuses on the modification of adnominal participles by means of still in combination with temporal adverbials, locative phrases, durative result stateoriented adverbials as well as external argument-oriented adverbials, instrumentals and by-phrases. Sections 4.1 and 4.2 investigate the semantics of the Polish equivalents of still as well as the relevant event and result state-oriented adverbials, while section 4.3 concentrates on the syntax and semantics of the change-of-state predicates and argues that the incompatibility of the modification of resultative adjectives by still and most types of event modifiers stems from the incompatibility of the presupposition triggered by still with the semantics of the measure-of-change function which returns the difference between the degrees to which the property holds at the end and at the beginning

2 The difference between ciagle and wciąz is a matter of register. Whereas the former is colloquial, the latter is a feature of the cultivated and literary language. In section 4.1., I argue that the difference between ciagle wcią $\dot{z}$ and jeszcze is in the nature of the implicature they trigger. 
of an event. In section 4.4 it is argued that participles that are compatible with still lack the inner aspectual specification and, therefore, constitute an extreme case of spatio-temporally uninstantiated event kinds. Section 5 offers some concluding remarks.

\section{Polish resultative adjectives are not reduced relative clauses}

Participial modifiers have traditionally been analyzed as relative clauses containing verbal (eventive) passives (see Kayne 1994; Rapp 2001; Laskova 2007; Cinque 2010; Sleeman 2011). Although it is not possible to address the said class of analyses in detail within the confines of this article, in what follows I present main reasons why Polish participial modifiers are not good candidates for reduced relative clauses.

In Polish, nouns may be pre- and post-modified by participles. (2) and (3) are semantically equivalent free variants with (3) being preferred by some speakers for stylistic reasons.

(2)

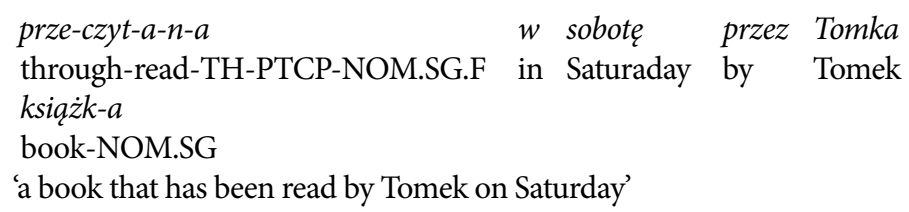

Under the radical version of the relative clause hypothesis ${ }^{3}(2)$ and (3) are born as (4), with the relative pronoun (która) and the auxiliary (została) unrealized and with a possible movement of the object noun and the participial predicate to a higher position.
(4) książka, która została prze-czyt-a-n-a book-NOM.SG which got through-read-TH-PTCP-NOM.SG.F w sobote przez Tomka in Saturday by Tomek 'a book that has been read by Tomek on Saturday'

${ }^{3}$ For different approaches analyzing participial modifiers as reduced relative clauses see Kayne (1994), Sleeman (2011), Laskova (2007) and Cinque (2010), among others. 
However, unlike English, Polish does not allow for the non-realization of the relative pronoun outside the context of ellipsis. ${ }^{4}$ Accordingly, relative clauses such as (4) and (5) must contain the relative pronoun.

(5) książk-a, *(która) Tomek prze-czyt-a-t

book-NOM.SG which Tomek through-read-TH-PTCP

'a book (that) Tomek read'

Additionally, Polish does not have a phonologically unrealized version of the auxiliary verb zostać 'get' which normally introduces verbal or eventive passives (Bondaruk and Rozwadowska 2018). Although verbless participial constructions such as (6a) are grammatical in Polish, the dropped element is the copula być 'be' that introduces resultative/adjectival passives. The verbless constructions do not license event modifiers such as temporal adverbials and byphrases as visible in (6b).

(6) a. walizk-i

$$
\text { (sa) } j u \dot{z}
$$

s-pak-owa-n-e!

suitcase-NOM.PL are already with-pack-TH-PTCP-NOM.PL.NVIR

'The suitcases have already been packed!'

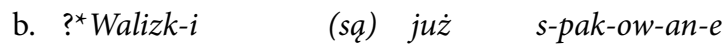
suitcase-NOM.PL (are) already with-pack-TH-PTCP-NOM.PL.NVIR wczoraj przez Romka! yesterday by Romek Int.: 'The suitcases were already packed yesterday by Romek!'

Moreover, Polish allows participial modifiers which cannot be found in predicative position.
a. $p r z y-b y-t-y$
gość
next-be-PTCP-NOM.SG.M guest-NOM.SG
'a guest that arrived'
b. ${ }^{*}$ gość, $\quad$ który jest/byt przy-by-t-y
guest-NOM.SG who is/was next-be-PTCP-NOM.SG.M
Intended: 'a guest who arrived'

Finally, Polish allows participial modification whose meaning is different from the (seemingly) corresponding relative clause. For example, the most natural reading of the unprefixed participles pisany and krojone found in $(8 \mathrm{a}-\mathrm{b})$ is the same as the reading of their perfective prefixed counterparts na-pisany 'written' and s-krojone ( $w$ kostke ) 'diced'. By contrast, the relative clauses found in (9) allow the present or past progressive reading or a habitual meaning where a particular

\footnotetext{
${ }^{4}$ Admittedly, the absence of the relative pronoun in putative reduced relatives may be due to the non-projection of the specifier of a defective $C$ rather than its non-realization. If that were the case, reduced relative clauses containing participles would be the only kind of relative clauses in Polish in which C does not project a specifier.
} 
kind of letter is or was customarily written with red ink and where a particular sort of vegetables is or was diced in accordance with a recipe. The key point is that the perfective resultative reading found in (8) is inconceivable for the relative clauses in (9). This is problematic for the analysis which claims that the clauses in (9) are the derivational source of (8).

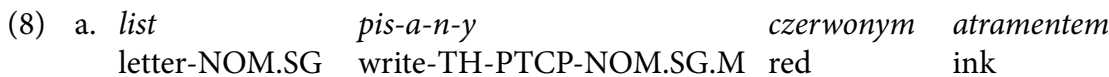
'a letter written in red ink'

b. kroj-on-ew kostke warzyw-a

slice-PTCP-NOM.PL.NVIR in dice vegetable-NOM.PL

'diced vegetables'

(9) a. list, który jest/byt pis-a-n-y

letter-NOM.SG which is/was write-TH-PTCP-NOM.SG.PL

czerwonym atramentem

red ink

'a letter that is/was (being) written in red ink'

b. warzyw-a, które sqa/byly kroj-on-e

vegetable-NOM.PL which are/were carve-PTCP-NOM.PL.NVIR

w kostke

in dice

'vegetables that are/were (being) diced'

The arguments above suggest that relative clauses are not the source of the preand post-modifying uses of passives in Polish.

\section{Constraints on the modification of adnominal participles}

\subsection{The modification by still}

Most Polish resultative adjectives are ambiguous between target and resultant states and have a reading in which an event gives rise to a transitory target state and a reading in which the resultant state is an irreversible consequence of the event having taken place.

As noted on multiple occasions (Kratzer 2000; Anagnostopoulou 2003, 2017; Alexiadou et al. 2015; Irmer and Mueller-Reichau 2018 and Bondaruk and Rozwadowska 2018 for Polish, among many others) only target state passives (but not the resultant state passives) accept the modification by the focus particle still. Moreover, Irmer and Mueller-Reichault (2018) claim that only target state passives may be modified by definite-time result state-oriented foradverbials. (10)-(12) present a selection of Polish resultative adjectives which do not accept the relevant modifiers. 
(10) a. ??ciagle wciążjeszcze prze-czyt-a-n-a ksiązk-a still1/still2 through-read-TH-PTCP-NOM.SG.F book-NOM.SG Intended: 'a book that is still read'

b. ??prze-czyt-a-n-a na rok książ-a through-read-TH-PTCP-NOM.SG.F for year book-NOM.SG Intended: 'a book that was read for a year'

(11) a. ??ciagle wciążjeszcze prze-kupi-on-y polityk still1/still2 through-buy-PTCP-NOM.SG.M politician-NOM.SG Intended: 'a politician that is still bribed'

b. ??prze-kupi-on-y na 2 lata polityk through-buy-TH-PTCP-NOM.SG.M for 2 years politician-NOM.SG Intended: 'a politician that is bribed for two years'

The participles found in (10) and (11) do not give rise to target states. In fact the entities involved do not undergo any change of state. The participles such as przeczytana 'read' or przekupiony 'bribed' are abstract perfect states arising as a consequence of the culmination of relevant events (see Parsons 1990).

However, as has already been noted by Kratzer (2000), the fact that a given participle is incompatible with still and for-adverbials does not mean that it is not a target state passive. The data in (12) illustrate the cases of participles that denote irreversible target sates. The unacceptable status of such participles with still and for-adverbials is the consequence of the incompatibility of the latter with irreversible states. While durative for/na-adverbials quite explicitly contain the terminating point of the state in their denotation, the German equivalent of still, i.e. immer noch, has been argued by Irmer and MuellerReichau (2018) to trigger an implicature whereby the time interval at which a property denoted by a participle holds is followed by a time interval at which the relevant property does not hold. ${ }^{5}$

(12) a. ??ciagle wcią̇̇/jeszcze $z$-mar-t-y/

still1/still2

za-mord-owa-n-y prezydent

for-murder-TH-PTCP-NOM.SG.M president-NOM.SG

Intended: 'a president who is still dead/murdered'

b. ??z-mar-t-y/ za-mord-owa-n-y

with-die-PTCP-NOM.SG.M for-murder-TH-PTCP-NOM.SG.M

na godzine prezydent

for hour president-NOM.SG

Intended: 'the president that was dead/murdered for an hour'

In what follows I focus on more complex patterns of modification.

\footnotetext{
${ }^{5}$ For the discussion of further conditions on the modification of participles by still, e.g. the incompatibility with script-final frames, I refer the reader to Irmer and Mueller-Reichau (2018).
} 


\subsection{Still in combination with state and event modifiers}

Most adjectival participles that introduce target states allow the modification by still and by means of manner adverbials, temporal (completion) adverbials as well as locative adverbials. This is true both about the resultative adjectives based on unaccusative verbs (13) and those based on transitive verbs (14). In addition, the latter allow for the modification by means of agent oriented adverbials such as specjalnie or celowo 'on purpose, intentionally', instrumentals as well as Polish equivalents of $b y$-phrases that introduce the external argument of the participle (see 15).

(13) a. ciagle wciążjeszcze za-kwit-ł-e wiśni-e still1/still2 for-flower-PTCP-NOM.PL.NVIR cherry-NOM.PL 'cherry trees that are still in bloom'

b. za-kwit-ł-e wczoraj wiśni-e for-flower-PTCP-NOM.PL.NVIR yesterday cherry-NOM.PL 'cherry trees that came into bloom yesterday'

c. szybko za-kwit-t-e wiśni-e quickly for-flower-PTCP-NOM.PL.NVIR cherry-NOM.PL 'cherry trees that quickly came into bloom'

d. wiśni-e za-kwit-ł-e w ogrodzie cherry-NOM.PL for-flower-PTCP-NOM.PL.NVIR in garden 'cherry trees that came into bloom in the garden'

(14) a. ciagle wciążjeszcze prze-mocz-on-e ubrani-e still1/still2 through-wet-PTCP-NOM.SG.N clothing-NOM.SG 'clothes that are still soaked'

b. prze-mocz-on-e w5 minut ubrani-e through-wet-PTCP-NOM.SG.N in 5 minutes clothing-NOM.SG 'clothes that have been soaked in five minutes'

c. blyskawicznie prze-mocz-on-e ubrani-e in a flash through-wet-PTCP-NOM.SG.N clothing-NOM.SG 'clothes that have been soaked in a flash'

d. ubrani-e prze-mocz-on-e $\quad w$ basenie clothing-NOM.SG through-wet-PTCP-NOM.SG.N in swimming pool 'clothes that have been soaked in the swimming pool'

(15) a. prze-mocz-on-e celowo woda ubrani-e through-wet-PTCP-NOM.SG.N purposefully water clothing-NOM.SG 'clothes that have been soaked on purpose with water'

b. prze-mocz-on-e przez Tomka ubrani-e through-wet-PTCP-NOM.SG.N by Tomek clothing-NOM.SG 'clothes that have been soaked by Tomek' 
The key observation that this paper is meant to account for is that the joint modification by means of the Polish equivalents of still and manner/temporal/locative/ agent-oriented phrases is ruled out in Polish resultative adjectives (see 16-17).

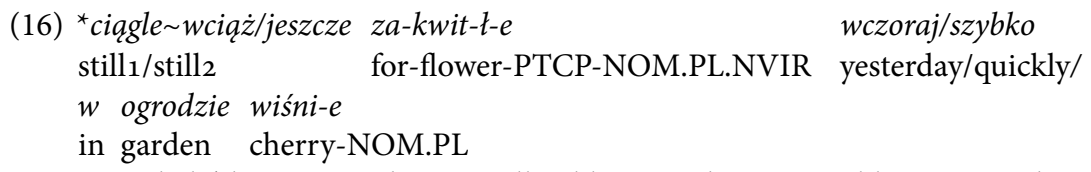

Intended: 'cherry trees that are still in bloom and came into bloom yesterday/quickly/in the garden'

(17) a. ${ }^{*}$ ciagle wciąż/jeszcze prze-mocz-on-e

still1/still2 through-wet-PTCP-NOM.SG.N

w 5 minut/ blyskawiczniel $w$ basenie ubrani-e

in 5 minutes in flash in pool clothing-NOM.SG

Intended: 'clothes that are still soaked and have been soaked in 5 minutes/in a flash/in the swimming pool'

b. ${ }^{\star}$ ciagle $\sim$ wciąż prze-mocz-on-e przez Tomka

still1/still 2 through-wet-PTCP-NOM.SG.N by Tomek

/celowo ubrani-e

purposefully clothing-NOM.SG

Intended: 'clothes that are still soaked by Tomek/on purpose'

At the same time the participles modified by still accept certain types of modification which are not found with underived root adjectives (18-19).

(18) a. ciagle wciążjeszcze obficie wy-petni-on-e

still1/still 2 lavishly out-full-PTCP-NOM.PL.NVIR

puchar-y

cup-NOM.PL

'cups that are still lavishly filled'

b. ciagle wciążjeszcze u-brudz-on-e na brunatno

still1/still 2 at-dirt-PTCP-NOM.SG.N on grey

ubrani-e

clothing-NOM.SG

'clothes that are still made grey from dirt'

(19) a. *obficie petn-e puchar-y

lavishly full-NOM.SG.NVIR cup-NOM.PL

Intended: 'cups that are lavishly full'

b. *brudn-e na brunatno ubrani-e

dirty-NOM.SG.N on grey clothing-NOM.SG

Intended: 'clothes that are grey from dirt'

Adverbials such as obficie 'lavishly' and na brunatno 'grey (lit. on grey)' modify the target state brought about by the event denoted by the participle. Building 
on this observation one could be tempted to formulate a generalization whereby the participles modified by still may be freely modified only by result state modifiers. Such a generalization would be largely correct, but at the same time too weak in that there are state modifiers which are incompatible with stillmodification. An example of such a class of modifiers is the class of durative result state-oriented adverbials introduced by $n a$.
(20) a. ${ }^{*}$ ciagle $w$ ciąż/jeszcze
still1/still2
wiśni-e
$z a-k w i t-t-e$
for-flower-PTCP-NOM.PL.M for 2 weeks
cherry-NOM.PL
Intended: 'cherry trees that came into bloom for 2 weeks and are still in bloom'
still1/still2 though-wet-PTCP-NOM.SG.N/
u-brudz-on-e nagodzine ubrani-e
b. ${ }^{*}$ ciagle wciąz/jeszcze prze-mocz-on-el
at-dirt-PTCP-NOM.SG.N for hour clothing-NOM.SG
Intended: 'clothes that have been soaked/made dirty for an hour and are still soaked/made dirty'

At the same time the state-modification by $n a$-adverbials may be accompanied by the event-modification by means of temporal completion adverbials (21a), manner adverbials (21b) as well as locative and by-phrases phrases (21c) and agent-oriented adverbials (21d).
(21) a. za-marz-nię-t-y $\quad w$ kilka godzin na
for-freeze-TH-PTCP-NOM.SG.M in several hours for
resztę zimy staw
rest winter pond-NOM.SG
'pond that has frozen in a couple of hours for the rest of the winter'
b. wy-łysi-a-ł-y błyskawicznie na reszte
out-bald-TH-PTCP-NOM.SG.M in a flash for rest
$\dot{z} y c i a \quad m e ̨ \dot{z} c z y z n-a$
life man-NOM.SG
'a man that became bald in a flash for the rest of his life'
c. most s-konstru-owa-n-y na poligonie
bridge-NOM.SG with-construct-TH-PTCP-NOM.SG.M on training ground
na czas przeprawy przez saperów
for time crossing by military engineers

'a bridge constructed by military engineers in the training ground for the time of the crossing'

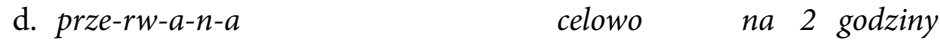

through-tear-TH-PTCP-NOM.SG.F purposefully on 2 hours

łączność radiow-a

communication-NOM.SG radio-NOM.SG.F

'radio communication that has been interrupted on purpose for two hours' 
Needless to say, none of the above phrases could be additionally modified by the Polish equivalents of still.

Moreover, state modifiers such as obficie 'lavishly' or na brunatno 'grey (lit. on grey)' are also compatible with event modifiers as illustrated in (22).

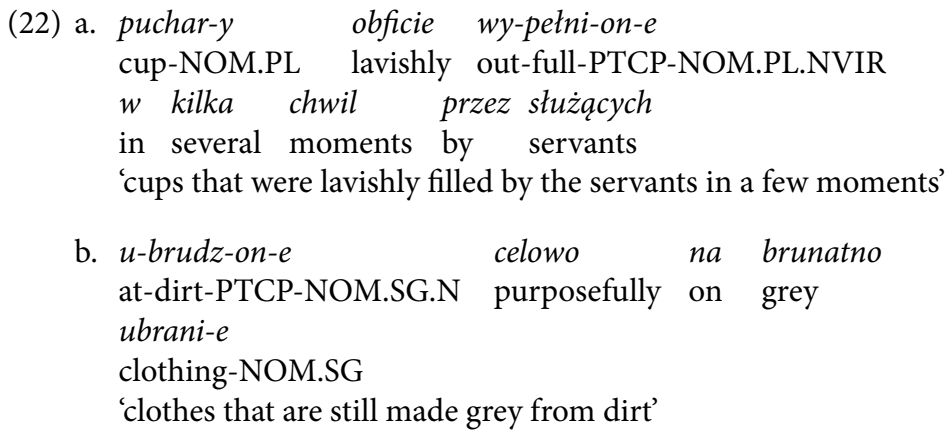

In sum, the modification of adnominal participles by the Polish versions of still is incompatible with event modification, including agent-oriented modifiers and $b y$-phrases (see 16-17), as well as result state-oriented for-adverbials (see 20). Still may, however, co-occur with result state modifiers such as the adverbial obficie 'lavishly', and result phrases such as na brunatno 'grey' (18). Absent still, virtually all kinds of modification may freely co-occur. Temporal completion adverbials, manner adverbials, locatives and agent-oriented modifiers are compatible with durative $n a$-adverbials as well as other result stateoriented modifiers (21-22).

\section{The analysis}

\subsection{The meaning contribution of still}

The analysis presented below has been influenced by the analyses of the German particle (immer) noch 'still' (see König 1991; Löbner 1999; Krifka 2000, Irmer and Mueller-Reichau 2018) and English still (see Ippolito 2007; Greenberg 2009) as focus or phase particles.

According to Löbner (1999), noch (immer) is a focus particle whose meaning depends on the nature of the focalized constituent in a sentence. In the case of the aspectual uses of noch (immer) focus scopes over the state predicate and contributes an assertion and a presupposition concerning the property that holds over two abutting time intervals.

In what follows I adopt the concept of 'relevant periods' from Greenberg's account of the meaning of still (Greenberg 2009: 72) to restrict the domain of existential quantification over the presupposed and asserted time intervals. To be precise, I assume that there is a relevant period $D$, which is a superinterval 
composed of (i) the time interval directly before the reference time and (ii) the time interval overlapping the reference time, and that the relevant property holds at the interval $\mathrm{D}$.

On these assumptions the assertion contributed by the Polish equivalents of still in (23a) is as in (23b) and acknowledges that wciaż/jeszcze 'still1/still2' says that the property of being soaked holds of the individual, i.e. the individual is soaked at least to degree $d$, at time $t$ which falls within the reference time.

$(23 \mathrm{c})$ is the truth condition that says that there exists a time interval $t$ which is a proper part of the superinterval $\mathrm{D}$ at which the entity is soaked, and that $t$ is a part of the reference time.

(23) a. ciagle wciążjeszcze prze-mocz-on-e still1/still2 through-wet-TH-PTCP-NOM.SG.N

ubrani-e

clothing-NOM.SG

'clothes that are still soaked'

b. $\lambda \mathrm{x} \lambda \mathrm{d} \lambda \mathrm{t}$.przemok $(\mathrm{x}) \geq(\mathrm{d})(\mathrm{t})$

where $t$ is part of the reference time identified by the tense of the sentence

c. $\exists \mathrm{t}[\mathrm{t} \subset \mathrm{D} \wedge \mathrm{t} \subseteq \mathrm{tr}]$

Following the majority of the literature on still I assume that ciagle wciaz and jeszcze as used in (23a) presupposes the existence of a contextually salient time interval directly preceding time $t$ at which some substantive degree of being soaked also held.

The component of the meaning of ciagle wciaz and jeszcze described above is retained in a question about a belief (24a) and when the assertion is denied by means of negation or by being placed in the antecedent of an unreal conditional clause $(24 b-c)$.

(24) a. Myślisz, że ubrani-e jest ciagle wciążjeszcze you think that clothing-NOM.SG is still1/still 2

prze-mocz-on-e? through-wet-PTCP-NOM.SG.N

'Do you think the clothes are still soaked now?'

b. To nie prawda, że ubrani-e jest ciagle wciąż/jeszcze

it not truth that clothing-NOM.SG is still1/still2

prze-mocz-on-e.

through-wet-PTCP-NOM.SG.N

'It's not true that the clothes are still soaked now.'

c. Gdyby ubrani-e byto ciagle wciaż/jeszcze

if clothing-NOM.SG was still1/still2

prze-mocz-on-e, suszytby je.

through-wet-PTCP-NOM.SG.N would dry it

'Were the clothes still soaked, he would be drying them.' 
The semantics of the presupposition together with its truth condition is presented in (25).

(25) a. $\lambda \mathrm{x} \lambda \mathrm{d}^{\prime} \lambda^{\prime} \cdot \operatorname{przemok}(\mathrm{x}) \geq\left(\mathrm{d}^{\prime}\right)\left(\mathrm{t}^{\prime}\right)$

b. $\exists \mathrm{t}^{\prime} \exists \mathrm{d}^{\prime}\left[\mathrm{t}^{\prime} \subset \mathrm{D} \wedge \mathrm{t}_{\text {INIT. }}^{\prime}=\mathrm{D}_{\text {INIT. }} \wedge \mathrm{t}^{\prime}<\mathrm{t} \wedge \mathrm{t}^{\prime} \supset \subset \mathrm{t} \wedge \mathrm{d} \leq \mathrm{d}^{\prime}\right]$

Ciagle wciaz and jeszcze presuppose the existence of a time interval $t^{\prime}$ that is the initial proper part of the focalized superinterval $D$, i.e. the initial subinterval of $t^{\prime}$ is the initial subinterval of $\mathrm{D}$, and that $\mathrm{t}^{\prime}$ precedes and abuts the interval t. (25) says also that at time t' the relevant entity was soaked to the degree which was greater than or equal to the asserted degree $d$.

Finally, (26) summarizes the semantic component of ciagle wciąz/jeszcze responsible for their incompatibility with participles denoting irreversible states (see 12 above). Irmer and Mueller-Reichau (2018) claim that the said component of the meaning of immer noch 'still' is an implicature that points to the existence of a time interval at which a relevant property does not hold and which is later than the reference time.

(26) a. $\lambda \mathrm{x} \lambda \mathrm{d}^{\prime \prime} \lambda \mathrm{t}^{\prime \prime} \cdot \operatorname{przemok}(\mathrm{x})=\left(\mathrm{d}^{\prime \prime}\right)\left(\mathrm{t}^{\prime \prime}\right)$

b. $\exists \mathrm{t}^{\prime \prime} \exists \mathrm{d}^{\prime \prime}\left[\mathrm{t}<\mathrm{t}^{\prime \prime} \wedge \mathrm{d}^{\prime \prime}=0\right]$

(26) says that ciagle wcią $\dot{z}$ and jeszcze trigger an inference according to which an entity is assigned value 0 on the scale of being soaked at interval t" which follows interval $t$.

It is probably useful to note that for most speakers the implicature triggered by ciagle wcią $\dot{z}$ is cancellable given the right context. This is illustrated by the sentence in (27a). At the same time, any attempts at cancelling the relevant meaning contribution of jeszcze is judged much less acceptable by the speakers I consulted.

(27) a. Basen jest ciagle/wciąż o-próżni-on-y pool-NOM.SG is still1 about-empty-PTCP-NOM.SG.M and zostanie o-próżni-on-y już na zawsze. will remain about-empty-PTCP-NOM.SG.M already for always 'The swimming pool is still emptied and it will remain emptied forever.'

b. ??Basen jest jeszcze o-próżni-on-y i pool-NOM.SG is still2 about-empty-PTCP-NOM.SG.M and zostanie o-próżni-on-y już na zawsze. will remain about-empty-PTCP-NOM.SG.M already for always Intended: 'The swimming pool is still emptied and it will remain emptied forever.'

To the extent that the component of meaning of the Polish equivalents of $\mathrm{im}$ mer noch is indeed an implicature, it may be concluded that it is the nature of the said implicature that differentiates between ciagle wciaz $\dot{z}$ and jeszcze in that only the implicature triggered by the former is defeasible the same time the two subclasses of particles share the same assertion and presupposition. 


\subsection{The meaning of other event and result state-oriented modifiers}

The analysis of temporal adverbials such as wczoraj 'yesterday' as well as manner, locative, instrument, resultative and agent-oriented adverbials assumed here follows the traditional Neo-Davidsonian lines. They are treated as semantic type $<$ s, $t>$ (see Morzycki 2015: chapter 5) and are assumed to attach at different levels of structure. I take the by/przez-phrase to be merged in the extended projection of Voice Phrase (see e.g. Bruening 2012) and to saturate the external argument of the participle. The example in (28) illustrates the modification of resultative adjectives with different types of adverbials.
(28) a. (ubrani-e) u-brudz-on-e do reszt-y, wczoraj, (clothing-NOM.SG) at-dirt-PTCP-NOM.SG.N to rest yesterday szybko, w garażu celowo farba, przez Tomka quickly in garage purposefully paint by Tomek 'clothes made completely dirty with paint, yesterday, quickly, in the garage, on purpose, by Tomek'

b. $\lambda \mathrm{e} \lambda \mathrm{s} \lambda \mathrm{d} .\left(\mathbf{d}>\mathbf{d}^{\prime}\right)(s)(e) \wedge \lambda$ e.wczoraj$(e) \wedge \lambda \operatorname{e.szybko}(e) \wedge \lambda \mathrm{e} . \mathrm{IN}($ garaż $)(e) \wedge \lambda \mathrm{e}$. celowo $(e) \wedge \lambda$ e.WITH $(\mathbf{f a r b a})(e) \wedge \lambda$ e.Initiator(Marek $)(e) \wedge \lambda$ e.u-brudz $(e)$ Where $\mathrm{d}^{\prime}$ is a contextually defined degree of being dirty above which one talks about being 'completely dirty'

Following Bruening $(2012,2014)$ I assume the modified nominal (in the case above ubranie 'clothing') not to be born as the internal argument of the participle but rather that the participial structure merges in the extended projection of the nominal phrase headed by the noun. The place of the internal argument is taken by an empty operator (lambda abstractor) that moves to the extended projection of the stativizing AP and allows the structure to function as a predicate of individuals.

(30) illustrates the position of the adverbials found in (28). The point of attachment of each class of adverbials can be deduced on the basis of their ungrammaticality is certain classes of verbs and participles. Thus, agent-oriented adverbials such as celowo 'on purpose' as well as by/przez-phrases and instrument adverbials such as farbq 'with paint' are absent in passive participles based on unaccusatives, which, by definition, do not introduce an external argument and lack the Voice layer altogether (see 29).

(29) a. ${ }^{*} z a-k w i t-t-e$ celowo kwiat-y for-flower-PTCP-NOM.PL.NVIR purposefully flower-NOM.PL Intended: 'flowers that came into bloom on purpose'
b. *pęk-nię-t-a kamieniem/przez Tomka szyb-a crack-TH-PTCP-NOM.SG.F stone by Tomek pane-NOM.PL Intended: 'a pane that was cracked with a stone/by Tomek' 
(30)

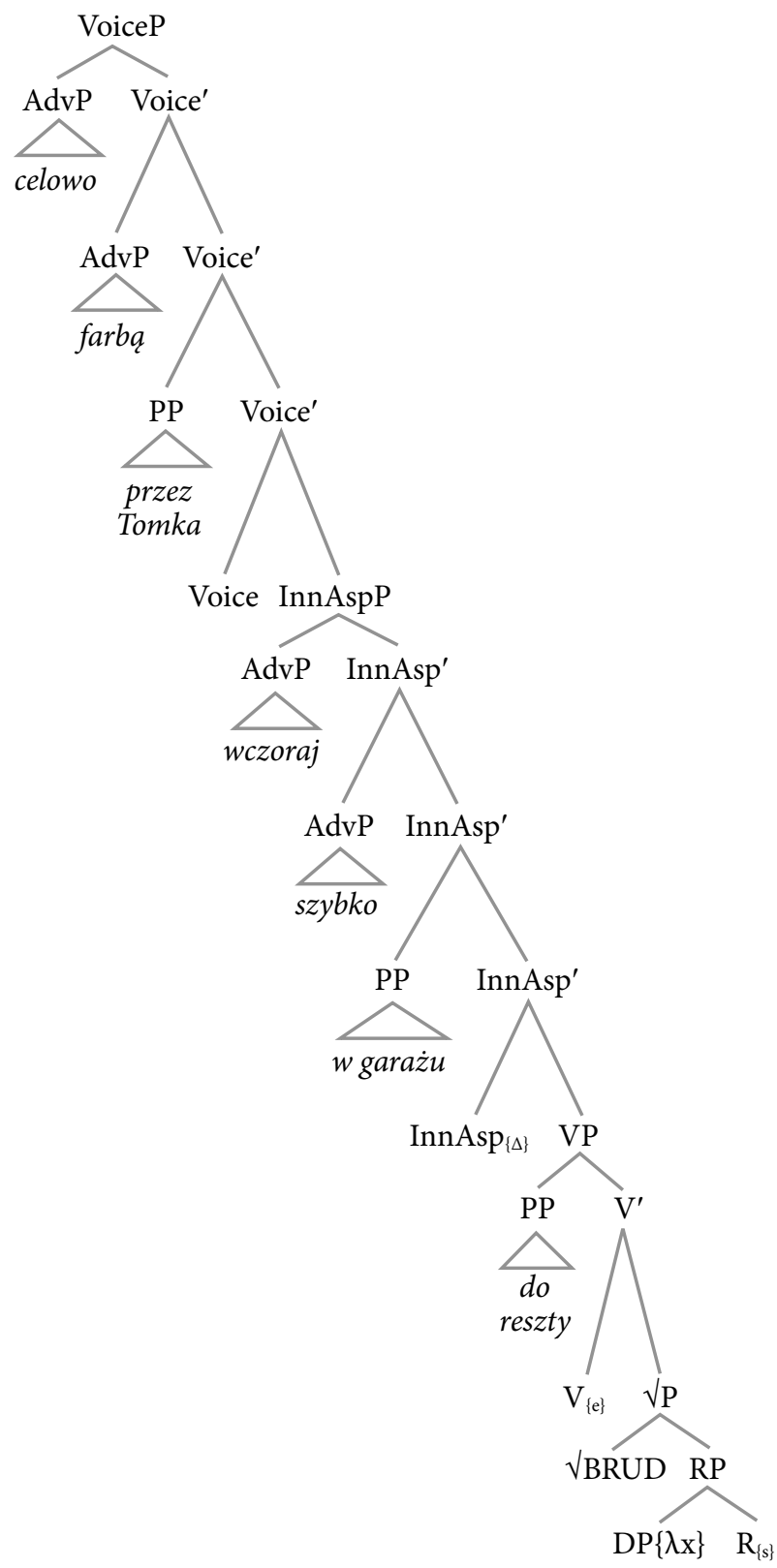

Manner adverbials such as szybko 'quickly', temporal adverbials of the type wczoraj 'yesterday' as well as locative adverbials intuitively modify the change of state denoted by the participles. Since I assume the change of state to be substantiated by the measure-of-change function introduced at the level of 
the Inner Aspect, the relevant adverbials are analysed as Inner Aspect-level adverbials. As I will argue in the following section, participles modified by the Polish equivalents of the particle still in principle cannot possess the Inner Aspect specification in their structure, hence, they are expected not to accept the modification by temporal, manner and locative adverbials.

Adverbials such as do reszty 'completely' (lit. 'to rest') as well as obficie 'lavishly' or na brunatno 'grey' may modify the passives of transitive and unaccusative verbs as well as the passives modified by still. They will be treated as result state modifiers and will be analyzed as VP level adverbials whose grammaticality is licensed by the presence of the state variable (introduced by the Result-head), the event variables (introduced by the V-head) and the semantic $\mathrm{R}$ (esult) relation between the two. Thus, the semantics of VP attested in (30) is as follows:

$$
\lambda d \lambda e \lambda s \lambda x \cdot\left[\exists s\left[\lambda d \lambda x \cdot \operatorname{brud}(x) \geq d \wedge d>d^{\prime} \wedge R(e)(x)(s)\right]\right]
$$

I take the denotation of the root to involve a mapping from an individual to the degree on a scale of being dirty.

Concerning the semantic contribution of durative for-adverbials, I will follow Piñon (1999) in assuming that durative result state-oriented adverbials are compatible only with predicates containing the result state argument. (32) presents the semantics of the phrase na 2 godziny 'for 2 hours' based on Piñón's (1999) account. The semantic interpretation of the adverbial incorporates the relation of Result (R) that involves the theme of the state assumed to be identified with the theme of event ( $\mathrm{x}$ ), the state argument (s) and the event argument (e). Piñón takes for to apply to predicates of states and to existentially bind the state argument. In the relevant case the predicate of state is the measure phrase godziny 'hours' treated as a measure function from states to degrees on the scale of number of hours.

(32) $\llbracket$ for $/ \mathrm{na} \rrbracket=\lambda \mathrm{P} \lambda \mathrm{R} \lambda \mathrm{x} \lambda \mathrm{e}[\mathrm{Gs}[\mathrm{R}(\mathrm{e}, \mathrm{x}, \mathrm{s}) \wedge \operatorname{hour}(s) \geq 2]]$ where $\mathrm{P}=\lambda \mathrm{d} \lambda$ s.hour $(s) \geq 2$

Finally, temporal completion adverbials will be given a familiar Neo-Davidsonian analysis. The phrase presented in (33) maps the event on a temporal scale of hours.

(33) a. prze-mocz-on-e w 2 godzin-y (ubrani-e) through-wet-PTCP-NOM.SG.N in 2 hour (clothing-NOM.SG) 'clothes that became soaked in two hours'

b. $\lambda$ e.przemocz $(e) \wedge \lambda \mathrm{d} \lambda$ e.hour $(e) \leq 2$

Whereas durative for/na-adverbials are VP-level modifiers, completion in/wadverbials will be introduced in the extended projection of the Inner Aspectual Phrase that decides about the telic or quantity character of the predicate. 


\subsection{The change-of-state component of resultative adjectives}

The analysis presented below has been strongly influenced by the approaches to the meaning and structure of degree achievements argued for in Hay et al. (1999), Kennedy and Levin (2008), Baglini (2012) and Bobaljik (2012) among others. I will start the account by discussing the semantic and syntactic structure of the participle prze-mocz-on-y 'through-wet-PTCP-NOM.SG.M, meaning 'soaked'.

The semantic packaging of the root $m o k^{-6}$ 'wet' is assumed to be a function from an individual to the degree on a scale of wetness $(\lambda \mathrm{d} \lambda \mathrm{x} \cdot \mathbf{m o k}(\mathrm{x}) \geq \mathrm{d})$. The root takes the Result Phrase as its complement. The Result-head introduces the state argument into the derivation.

The root merges with the categorizing V-head, which introduces the event variable into the structure. The verbalized root is subsequently merged with the inner aspectual head that carries the $\Delta$-operator, whose role is to introduce the measure-of-change function wet $\Delta=\lambda \mathrm{x} \lambda \mathrm{e}$. The said function returns the difference between two points on a derived scale of wetness whose lowest point coincides with the initial point of the event. The returned value is the difference between the degree to which the entity is wet at the final point of the event and at the initial point of the event.

The next step in the derivation involves turning the so-far unbounded predicate into a bounded or telic predicate. The structural interpretation of telicity assumed in this study is the presence of the open value (\#) in need of range assignment in the head of another inner aspectual phrase (InnAsp2P). Adopting the account presented in Borer (2005), I will assume that the range assignment takes place as a consequence of the spec-head agreement between the Inner Aspectual-head carrying the said open value and the phonologically null quantity DP located in the spec-InnAsp2P. The relevant DP is the complement of the prefix that heads a PP merged in the specifier of the InnAsp2P. (34) presents the relevant portion of the representation of a telic change-of-state verb przemoczyć 'to soak.' and the participle przemoczony 'soaked'.

${ }^{6}$ The alternation between the velar $k / \mathrm{k} /$ and the post-alveolar $c z / \mathrm{t} \mathrm{j} /$ attested in the stem of the participle przemoczony is a regular morphophonological change known as the $1^{\text {st }}$ Velar Palatalization (see Gussmann 1980, 2007; Rubach 1984 for details and analyses). 


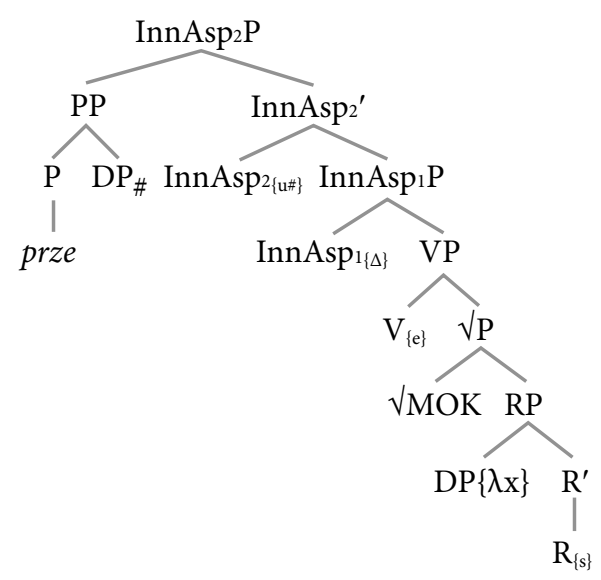

The key point of the analysis put forward in this study is that the semantics of the structure presented in (34) makes it incompatible with the modification by the Polish equivalents of still. To understand why this has to be the case, let us consider (35b), which breaks down the application of the measure-of-change function mok $\Delta$ applied to individuals and events and returning the difference between d', i.e. the degree to which the property holds over $\mathrm{x}$ at the end of the event $(\operatorname{END}(e))$, and d, i.e. the degree to which a property holds at the beginning of the event $(\mathrm{BEG}(\mathrm{e}))$.

(35) a. prze-mocz-on-e w 5 minut ubrani-e through-wet-PTCP-NOM.SG.N in 5 minutes clothing-NOM.SG 'clothes that became soaked in 5 minutes'

b. $\lambda e \lambda x \lambda d \lambda d^{\prime} \lambda \operatorname{Pamok}(B E G(e))(x)(d) \wedge(\operatorname{END}(e))(x)\left(d^{\prime}\right) \wedge$ minute $\left.(e) \leq 5\right)$ where $\mathrm{P}=\lambda \mathrm{e} \lambda \mathrm{d}$.minute $(\mathrm{e}) \leq 5$

Importantly, for the proposition contained within (35a) to be true, the entity could not have been entirely wet (i.e. wet in every part) at the inception of the event. (35a) says, rather, that the entity has undergone a change from not being entirely wet to being entirely wet, and that this state has been achieved in (no more than) 5 minutes.

It is quite clear that the point of attachment of the completion in/w-adverbials is as the modifier of Asp2 $\mathrm{P}$ that defines the predicate as quantized, bounded or telic. At the same time the point of attachment of still and its Polish equivalents is above the stativizer, which I take to be the TARGET-operator occupying the head of the AP and assumed by Paslawska and von Stechow (2003) to map a relation between events and states onto properties of states (see 36).

(36) $\lambda \mathrm{R} \lambda \mathrm{s}$ 寻 R(s)(e) (Kratzer 2000, Paslawska and von Stechow 2003) 
To be more precise, I assume still to occupy the Particle Phrase (PartP) in the extended projection of the Adjectival Phrase that categorizes the participle. The graph in (37) presents the placement of the modifiers in question in the structure.

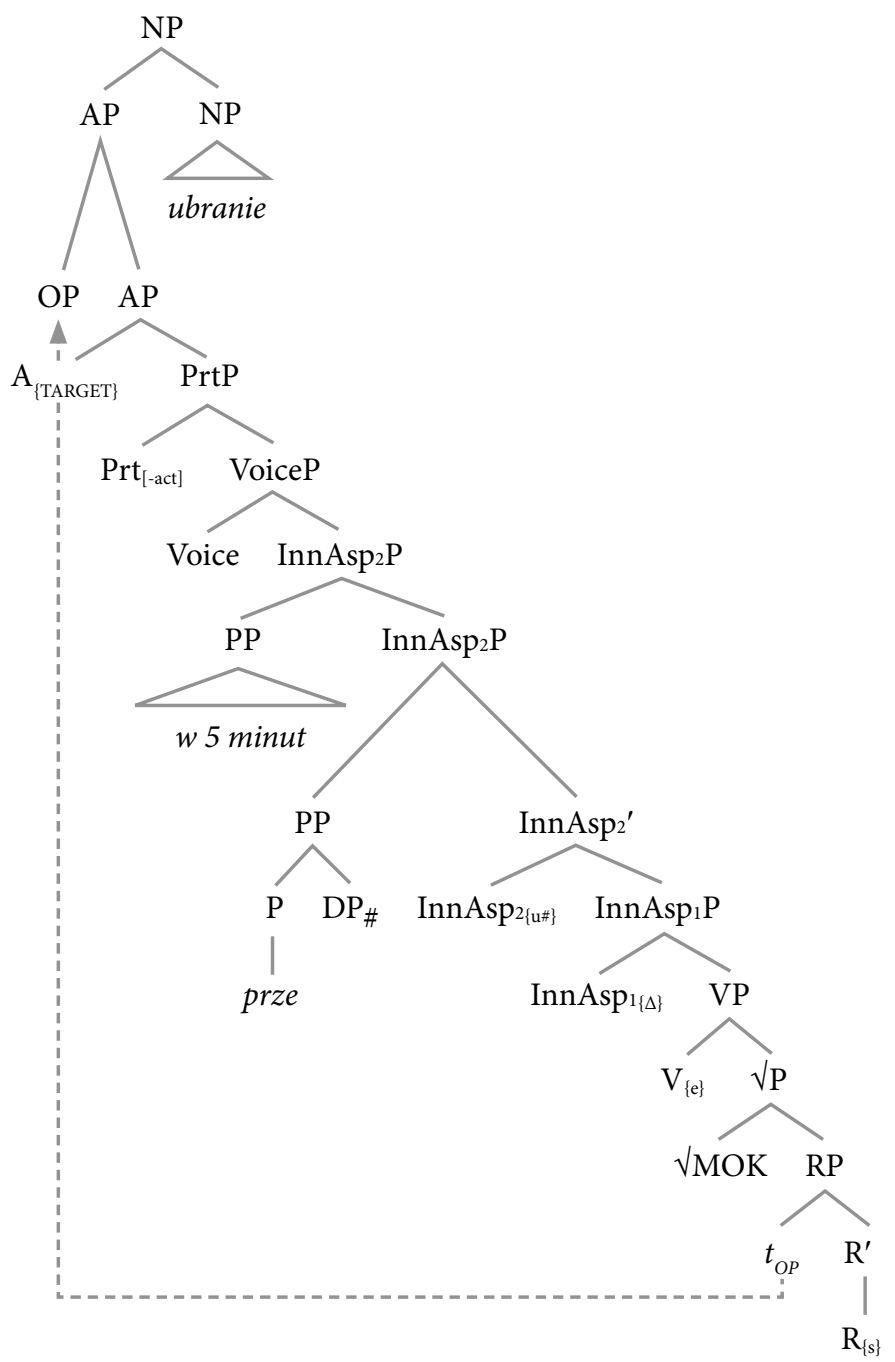

Recall that the focus of the constructions under investigation is the predicate of state mapped onto the superinterval D throughout which a focalized property holds. In the relevant case, it is the property of being entirely wet. Syntactically speaking, the focus is congruent with the c-command domain of the particles ciagle wciaż/jeszcze. In other words, the property of being entirely wet holds of the state predicate defined by the TARGET-operator. 
At this point it becomes clear why the modification by still is incompatible with the representation of a change-of-state predicate. The presence of the change of state entails the existence of an interval within the scope of the focus particle at which not every part of the clothes is wet. This is incompatible with the semantic contribution of still, which requires that the state of being entirely wet, i.e. soaked, hold throughout the superinterval D. The unacceptability of the phrase found in (38) is illustrated by means of the graph in (39).
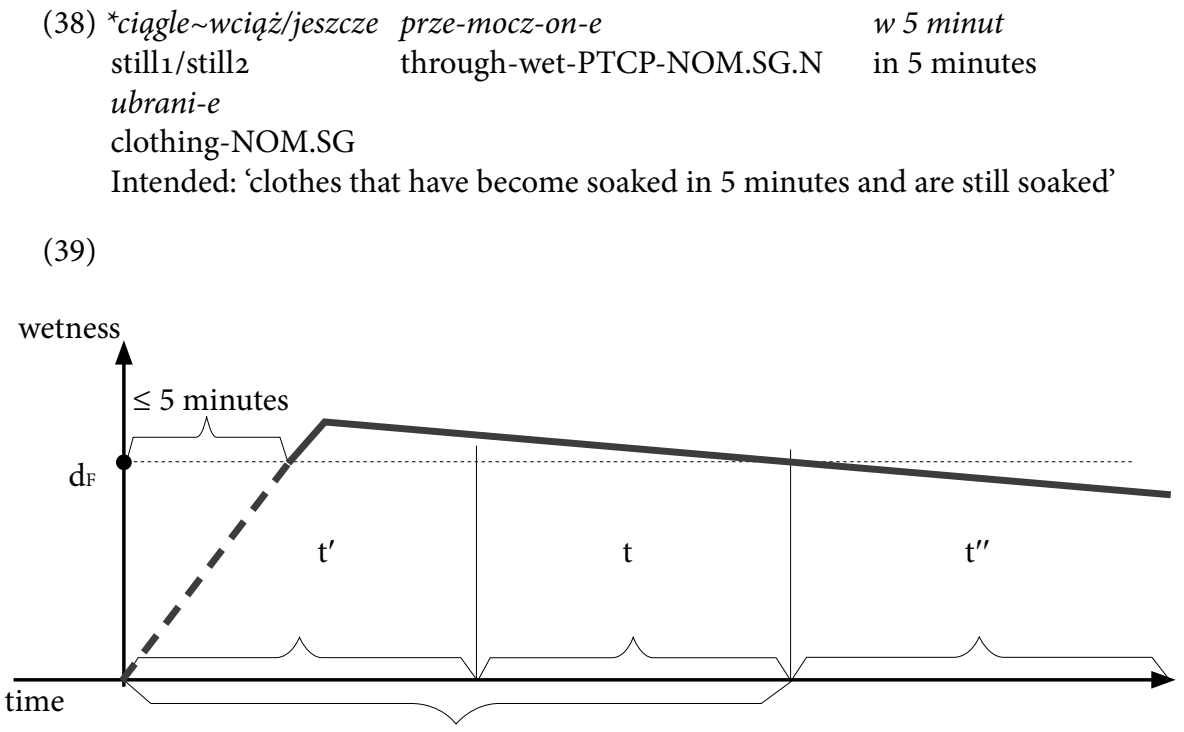

The graph presents the interaction of the scale of wetness and the time scale. The degree of wetness expressed by the predicate in (38) relative to time is represented by means of the bold line. $\mathrm{dF}$ represents the contextually salient point on the scale of wetness defined by the prefix above which the entity counts as entirely wet (much as in Kagan 2013). D is the relevant period at which the property of being entirely wet is expected to hold or, to put it differently, at which the truth condition of the focalized predicate of state is expected to be fulfilled. As discussed in section 4.1 the said truth condition includes the assertion concerning the interval $t$ which is identified as part of the reference time and a presupposition of the interval $t$ ' which abuts $t$ and is the initial proper subinterval of $D$. Still is also claimed to implicate the existence of an interval $t$ " after $t$ at which the property of being entirely wet does not hold anymore. This is illustrated in (39) by the bold line descending below the level marked with the horizontal dashed line, which represents the level of being entirely wet (or soaked). The predicate represented by (39) is unacceptable due to the existence of the 5-minute-long interval which falls within the focalized superinterval $\mathrm{D}$ and during which the entity is not entirely wet. This interval, indicated by 
means of the dashed bold line, is the interval during which the change of state from not being entirely wet to being entirely wet takes place. To be more precise, the existence of the said interval contradicts the truth condition of the presupposition triggered by ciagle wcią $\dot{z} / j e s z c z e$, which says that the property of being entirely wet should hold over the initial proper interval of $D$.

According to the account outlined above, completion adverbials that measure the duration of the event as well as other temporal, manner and locative adverbials are not incompatible with still per se. It is rather the case that still is incompatible with the change-of-state component of the meaning of participles, and that the presence of the change-of-state component is the prerequisite for the grammaticality of temporal, manner and locative adverbials, which all modify the change of state.

\subsection{Participles modified by still}

The issue that obviously needs to be addressed at this point is why most target state resultative adjectives actually allow the modification by still. I would like to postulate that those participles do not contain the $\Delta$-operator that introduces the measure-of-change function. Additionally, the participles accompanied by still will be claimed to constitute an extreme case of uninstantiated event kind-based participles, whose compatibility with modifiers is regulated by the State Relevance Hypothesis (McIntyre 2013, 2015).

The idea that (stative) adjectival participles are constructed on uninstantiated event kinds has been articulated in Gehrke $(2011,2015)$. According to the Gehrke's original analysis, statives lack the viewpoint aspectual specification that instantiates the event forming part of the participle. For such an account, all the participles discussed in this article are uninstantiated as all of them lack the viewpoint aspectual specification. At the same time, unlike adjectival participles in predicative position, the adnominal participles accept a wide variety of modifiers, except for when they are accompanied by the phase particles equivalent to still.

In the light of these facts, it seems justified to claim that for Polish adnominal participles it is not the lack of the viewpoint aspectual specification that decides about the (un)availability of event modification but rather the presence and absence of inner aspectual specification. To be precise, the participles modified by still that do not contain the change-of-state component function as uninstantiated event-kind based participles and may be accompanied only by modifiers which possess a very specific relation to the result state they denote.

McIntyre $(2013,2015)$ discusses the scope of various constraints on event modification attested in the environment of adjectival participles and proposed by Gehrke $(2011,2015)$. He puts forward an additional constraint which he refers to as the State Relevance Hypothesis (see 40). 
(40) State Relevance Hypothesis (McIntyre 2013, 2015)

In adjectival passives in e.g. German, English, Hebrew, event-related satellites are unacceptable unless they contribute to the description of the state expressed by the participle or of the theme during the interval $i$ during which this state holds. They are most acceptable if they provide information which can be inferred solely by inspection of the theme during interval $i$.

The modification of resultative adjectives accompanied by the Polish equivalents of still is constrained by the State Relevance Hypothesis. Note that the participles found in the scope of still may be accompanied by some modifiers which are unattested with adjectives and which, therefore, count as 'event-related satellites' (see 41).

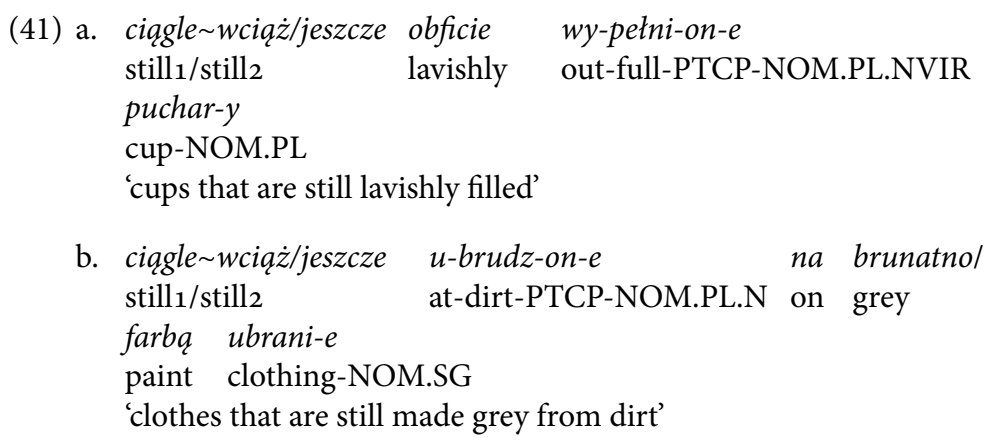

Result state modifiers such as obficie 'lavishly', na brunatno 'grey' as well as the Voice-layer modifiers such as farba 'with paint' describe the properties whose presence can be 'inferred solely by inspecting the theme' during the interval over which the properties of being filled or being dirty hold. They may, therefore, be attested in the environment of the extreme case of spatio-temporally uninstantiated event kind-based participles, i.e. participles compatible with still. At the same time, the fact that the relevant type of modifiers is not attested with adjectives suggests that the still-modified resultative adjectives possess at least some portions of the verbal structure found in event token-based participles.

In addition, if we assume that the still-modified participles are necessarily based on aspectually uninstantiated event kinds and that the modification of such predicates is constrainted by the State Relevance Hypothesis, we account for their incompatibility with durative result state-oriented for/na-adverbials (see 42).

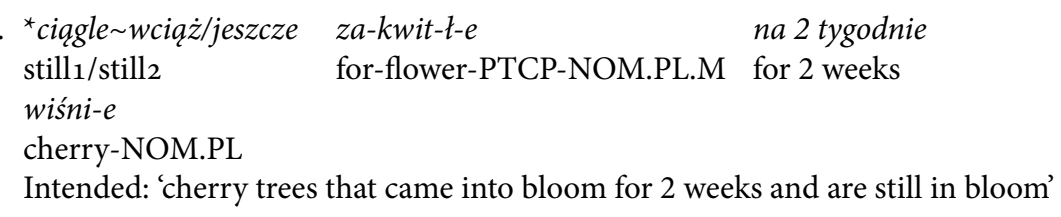


b. *ciagle wciążjeszcze prze-mocz-on-el

still1/still2

though-wet-PTCP-NOM.SG.N/

u-brudz-on-e nagodzine ubrani-e

at-dirt-PTCP-NOM.SG.N for hour clothing-NOM.SG

Intended: 'clothes that have been soaked/made dirty for an hour and are still soaked/made dirty'

Although durative for-adverbials are result state modifiers, their presence does not conform with the State Relevance Hypothesis as it is not possible to tell for how long cherry trees have been in bloom or for how long a piece of clothing has been soaked/dirty by simply inspecting them physically, e.g. looking at them or touching them.

(44) summarizes the structure of the still-modifiable resultative adjective found in (43).

(43) ciagle wciążjeszcze prze-mocz-on-e ubrani-e still1/still2 though-wet-PTCP-NOM.SG.N 'clothes that are still soaked'

clothing-NOM.SG

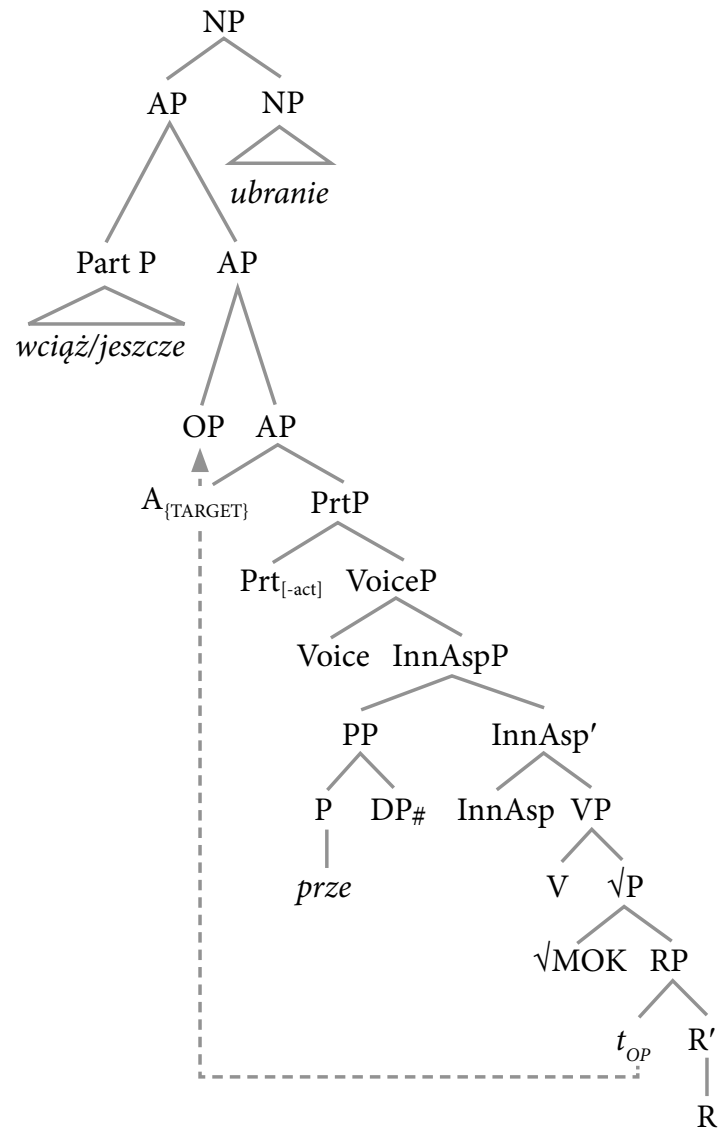


The structure in (44) lacks the inner aspectual specification responsible for the change-of-state semantics as well as the open value in need of range assignment. At the same time the state(-kind) expressed by the structure is a result of the event(-kind), hence it may be modified by adverbials which are not accepted by underived root adjectives.

\section{Conclusion}

Out of the several questions that one might want to ask in connection with the analysis presented in this paper I think I should address the one concerning the place of the postulated participles among the cross-linguistically attested classes of passives. This contribution isolates two subclasses of participles which are not specified for viewpoint aspect: (i) participles built on telic events possessing the measure-of-change function within their structure and (ii) participles built on event kinds lacking the measure-of-change component. The division certainly does not overlap with the division into the target state and resultant state passives discussed in Kratzer (2000), Anagnostopoulou (2003, 2017), Alexiadou et al. (2015) and Bondaruk and Rozwadowska (2018) for Polish. Rather the two subclasses discussed here are target state passives in that they possess a modifiable target state and are not just abstract perfect states arising as a result of the culmination of the event. Moreover, although the class of still-modifiable participles is deprived of much of the aspectual information, it is still a class of resultatives rather than statives (see Embick 2004 for the distinction between resultatives and statives). Polish possesses a separate class of constructions which are completely deprived of eventive semantics and give rise to adverbials. These are participles such as wzniosty 'lofty, noble', wytrwaty 'durable', przestarzaty 'old-fashioned' or zacofany 'backward'. It seems, therefore, that the two classes of participles discussed in this study illustrate an additional line of division within the class of resultative target state passives.

\section{References}

Alexiadou Artemis, Anagnostopoulou Elena, Schäfer Florian (2015). External Arguments in Causativity Alternations: A Layering Approach. Oxford: Oxford University Press.

Anagnostopoulou Elena (2003). Participles and voice. In Perfect Explorations, Artemis Alexiadou, Monika Rathert, and Arnim von Stechow (eds.), 1-36. Berlin: Mouton de Gruyter.

Anagnostopoulou Elena (2017). Voice, manners, and results in adjectival passive. In The Verbal Domain, Roberta D’Alessandro, Irene Franco, and Ángel J. Gallego (eds.), 105-128. Oxford: Oxford University Press. 
Baglini Rebekah (2012). The scalar source of stative passives. In Proceedings of Sinn und Bedeutung 16, Ana Aguilar Guevara, Anna Chernilovskaya, and Rick Nouwen (eds.), 29-41. Utrecht, The Netherlands: MIT Working Papers in Linguistics.

Bobaljik Jonathan (2012). Universals in Comparative Morphology. Cambridge, MA: MIT Press.

Bondaruk Anna, Rozwadowska Bożena, (2018). Heterogenity of states in Polish stative passives. In Canonical and Non-canonical Structures in Polish, Wojciech Guz and Bogdan Szymanek (eds.), 33-53. Lublin: Wydawnictwo KUL.

Borer Hagit (2005). Structuring Sense Volume II: The Normal Course of Events. Oxford: Oxford University Press.

Bruening Benjamin (2012). By phrases in passives and nominals. Syntax 16(1): 1-41.

Bruening Benjamin (2014). Word formation is syntactic: adjectival passives in English. Natural Language and Linguistic Theory 32(2): 363-422.

Cetnarowska Bożena (2000). Resultative adjectives in Polish. Acta Linguisticsa Hungarica $47(1-4), 47-79$.

Cinque Giulglielmo (2010). The Syntax of Adjectives. A Comparative Study. MIT Press, Cambridge, MA.

Embick David (2004). On the structure of resultative participles in English. Linguistic Inquiry 35(3), 355-392.

Gehrke Berit (2011). Stative passives and event kinds. In Proceedings of Sinn und Bedeutung 15, Ingo Reich, Eva Horch, and Dennis Pauly (eds.), 241-257. Saarland University Press. Saarbrücken.

Gehrke Berit (2015). Adjectival participles, event kind modification and pseudo-incorporation. Natural Language and Linguistic Theory 33(3), 897-938.

Greenberg Yael (2009). Presupposition accommodation and informativity considerations with aspectual still. Journal of Semantics 26(1), 49-86.

Gussmann Edmund (1980). Studies in Abstract Phonology. Cambridge, MA: MIT Press.

Gussmann Edmund (2007). The Phonology of Polish. Oxford: Oxford University Press. Hay Jennifer, Kennedy Christopher, Levin Beth (1999). Scalar structure underlies telicity in Degree Achievements. In Proceedings of SALT IX, Tanya Matthews and Devon Strolovitch (eds.), 127-144. Ithaca, NY: CLC Publications.

Ippolito Michela (2007). On the meaning of some focus-sensitive particles. Natural Language Semantics 15(1), 1-34.

Irmer Matthias, Mueller-Reichau Olav (2018). Script knowledge and the felicity of phase particles in German adjectival passives. Journal of Semantics 35(4), 585-637.

Kagan Olga (2013). Scalarity in the domain of verbal prefixes. Natural Language and Linguistic Theory 31(2), 481-516.

Kayne Richard (1994). The Antisymmetry of Syntax. Cambridge, MA: MIT Press.

Kennedy Christopher, Levin Beth (2008). Measure of change: The adjectival core of degree achievements. In Adjectives and Adverbs: Syntax, Semantics and Discourse, Louise McNally and Christopher Kennedy (eds.), 156-182. Oxford: Oxford University Press.

König Ekkehard (1991). The Meaning of Focus Particles. A Comparative Perspective. London and New York: Routledge.

Kratzer Angelika (2000). Building statives. In Proceedings of the Twenty-Sixth Annual Meeting of the Berkeley Linguistics Society, Lisa J. Conathan, Jeff Good, Darya 
Kavitskaya, Alyssa B. Wulf, and Alan C.L. Yu (eds.), 385-399. Berkeley: Berkeley Linguistics Society.

Krifka Manfred (2000). Alternatives for aspectual particles: semantics of still and already. In Proceedings of the Twenty-Sixth Annual Meeting of the Berkeley Linguistics Society General Session and Parasession on Aspect, Lisa J. Conathan, Jeff Good, Darya Kavitskaya, Alyssa B. Wulf, and Alan C.L. Yu (eds.), 401-412. Berkeley: Berkeley Linguistics Society.

Laskova Vesselina (2007). Verbal participles and the prenominal position in English. Rivista di Grammatica Generativa 32, 125-140.

Löbner Sebastian (1999). Why German schon and noch are still duals: A reply to van der Auwera. Linguistics and Philosophy 22(1), 45-107.

McIntyre Andrew (2013). Adjectival passives and adjectival participles in English. In Non-canonical Passives, Artemis Alexiadou and Florian Schäfer (eds.), 21-41. Amsterdam/Philadelphia: John Benjamins.

McIntyre Andrew (2015). Event modifiers in (German) adjectival participles: Remarks on Gehrke. Natural Language and Linguistic Theory 33(3), 939-953.

Morzycki Marcin (2015). Modification. Cambridge: Cambridge University Press.

Parsons Terence (1990). Events in the Semantics of English. Cambridge, MA.: The MIT Press.

Paslawska Alla, von Stechow Arnim (2003). Perfect readings in Russian. In Perfect Explorations, Artemis Alexiadou, Monika Rathert, and Arnim von Stechow (eds.), 307-362. Berlin: Mouton de Gruyter.

Piñón Christopher (1999). Durative adverbials for result states. In Proceedings of the West Coast Conference on Formal Linguistics, Sonya Bird, Andrew Carnie, Janson D. Haugen, and Peter Norquest (eds.), 420-433. Somerville, MA: Cascadilla Press.

Rapp Irene (2001). The attributive past participle: Structure and temporal interpretation. In Audiatur Vox Sapientiae: A Festschrift for Arnim von Stechow, Caroline Féry and Wolfgang Sternefeld (eds.), 392-409. Berlin: Akademie Verlag.

Rubach Jerzy (1984). Cyclic and Lexical Phonology: The Structure of Polish. Dordrecht: Foris.

Sleeman Petra (2011). Verbal and adjectival participles: Position and internal structure. Lingua 121(10), 1569-1587.

Sławomir Zdziebko

Instytut Językoznawstwa

Katolicki Uniwersytet Lubelski Jana Pawła II

Al. Racławickie 14

20-950 Lublin

Poland

s.zdziebko86(at)gmail.com

ORCID: 0000-0001-8303-8773 